\title{
Allelopathic effect of Sorghum bicolor and Digitaria insularis on germination and initial development of Canola
}

\author{
Thiago Souza Campos ${ }^{1}$, Ane Gabriele Vaz Sousa ${ }^{1}$, Jaime Santos do Rego Junior ${ }^{1}$, Westefann \\ dos Santos Sousa ${ }^{1}$, Cleiton Gredson Sabin Benett ${ }^{1}$, Natália Arruda ${ }^{1}$
}

\begin{abstract}
${ }^{1}$ Universidade Estadual de Goiás, Campus Sudeste, Unidade Ipameri, Ipameri, Goiás, Brasil. E-mail: thiagocamposagr@gmail.com, anevazsouza@gmail.com, jaimeagronomia@gmail.com,westefannsantos@hotmail.com, cleiton.benett@gmail.com,

nathy.a@hotmail.com
\end{abstract}

Received: 08/01/2020; Accepted: 06/08/2020.

\begin{abstract}
Agriculture depends on biotic and abiotic factors, and one of them is allelopathy, defined as the chemical interference that one plant has on others, which can negatively affect germination. The objective of this work is to evaluate the allelopathic effects of Sorghum bicolor and Digitaria insularis on seed germination and initial development of canola seedlings (Brassica napus L.). A completely randomized design was used in a $2 \times 5$ factorial scheme (two extracts: D. insularis and S. bicolor) and five concentrations (0, 25, 50, 75, and 100\%), with four replicates of fifty seeds, the plot being constituted by a 'gerbox' box containing 50 seeds evenly distributed. The variable analyzed were germination percentage $(G)$, abnormal seedlings (AS), dead seeds (DS), length of the shoot (SL) and primary root (RL), total length (TL) of the seedling, shoot ratio (S/T), and root ratio (R/T). The aqueous extracts of $D$. insularis interfere in all variables studied, which compromises the formation of normal seedlings, regardless of concentration. The extract of S. bicolor expressed allelopathic effects only in concentrations above $75 \%$. Both species can inhibit the initial development of canola plants.
\end{abstract}

Keywords: allelochemicals, inhibition, Brassica napus.

\section{Efeito alelopático de Sorghum bicolor e Digitaria insularis na germinação e desenvolvimento inicial da Canola}

\section{RESUMO}

A agricultura é refém dos fatores bióticos e abióticos, e um desses fatores é a alelopatia, que se trata da interferência química que uma planta exerce sobre a outra, podendo provocar efeito negativo na germinação. O objetivo deste trabalho é avaliar os efeitos alelopáticos do Sorghum bicolor e Digitaria insularis na germinação de sementes e no desenvolvimento inicial de plântulas da canola (Brassica napus L.). Utilizou-se o delineamento inteiramente casualizado em esquema fatorial $2 \times 5$ (dois extratos: $D$. insularis e $S$. bicolor) e cinco concentrações $(0,25,50,75$ e $100 \%$ ), com quatro repetições de cinquenta sementes, sendo a parcela constituída por uma caixa 'gerbox' contendo 50 sementes uniformemente distribuídas. As análises realizadas foram: porcentagem de germinação (G), plântulas anormais (PA), sementes mortas (SM), comprimento da parte aérea (CA) e da raiz primária (CR), comprimento total (CT) da plântula, razão da parte aérea (AT) e razão da raiz (RT). Os extratos aquosos de $D$. insularis interferem em todas as variáveis estudadas, o que compromete a formação de plântulas normais, independente da concentração. O extrato de S. bicolor expressou efeitos alelopáticos apenas em concentrações acima de $75 \%$. Ambas as espécies possuem capacidade de inibir o desenvolvimento inicial da cultura da canola.

Palavras-chave: aleloquímicos, inibição, Brassica napus. 


\section{Introduction}

Canola (Brassica napus L.) is an agricultural product of great economic value due to its flexibility, being used both in human and animal consumption and biofuels production. It is the third oilseed most produced in the world, with around 67.8 million tons in the 2018/2019 harvest, having Canada as its main producer, with a production of around 28.5 million tons and in second position, the Union European Union, with a production of 20 million tons, being the largest consumer (24.3 million tons). Brazil has a low production, with 52 thousand tons in the 2019 harvest (EMBRAPA, 2018; USDA, 2019). Brazilian production is intended for oil production, derived from the genetic improvement of Brassica napus and Brassica campestris, to minimize the content of erucic acid and glucosinolates, enabling digestibility and palatability (Seabra Júnior et al., 2017).

Canola is used in Brazil as a winter crop and as an alternative in the crop rotation system, collaborating to reduce phytosanitary problems of crops of great economic weight such as soybeans, beans, corn, and wheat (Cargnelutti et al., 2015). It can also be used as a vegetal covering of the soil, being the species most cultivated in the country Brassica napus L. var. oliferous, where its late cultivation in winter could contribute to optimizing the use of agricultural resources further, also creating another income opportunity for farmers (Milciades et al., 2014).

Brazilian agriculture faces several biotic and abiotic factors that compromise the success of the crop; one of these factors is the competition between the establishment of the crop and the presence of weeds, highlighting the allelopathic effect as one of the limiting aspects of the presence of invasive plants, due to chemical interference that can negatively impact germination (Uhlmann et al., 2018). Lessa et al. (2019) define allelopathy as the interaction between chemical molecules produced by secondary metabolism and released into the environment, occurring changes that are generally harmful to the development of another plant. Allelochemical compounds can be produced in various parts of plants, from the root to the leaves, being released by living or dead tissues; the intensity by which the species are affected will depend on the quantity and concentration of these compounds in the environment (Souza Filho, 2014).

Allelopathy, as far as it is concerned, can occur due to the action of a weed exuding chemical substances harmful to the development of plants of the same or different species. Gonçalves et al. (2015) stated that several weeds have an allelopathic capacity that affects the development of commercial plants, such as rice grass (Echinochloa crusgalli), mattress grass (Digitaria horizontalis), and foxtail grass (Setaria faberil).
Among the species that have allelopathic potential, sorghum (Sorghum bicolor) stands out for the production of secondary compounds with allelopathic action, more specifically sorgoleone, a lipid benzoquinone produced in the shoot and in the root system of sorghum plants, which is phytotoxic to several plant species (Dayan et al., 2009). According to Dayan and Duke (2014), sorgoleone from the roots is diffused in the rhizosphere, reaching plants faster than the phytotoxins released by the shoot.

Digitaria insularis (sourgrass) is also classified as an allelopathic crop. The increase in agricultural areas demonstrates allelopathic effects on the corn crop, interfering in the development of the plant (Moreira and Mandrick, 2012). The potential for weed interference can vary according to climatic conditions and production systems.

Thus, this study aimed to evaluate the allelopathic effects of Sorghum bicolor and Digitaria insularis on seed germination and early development of Canola (Brassica napus L.).

\section{Material and Methods}

The experiment was conducted at the Seed Laboratory (LASEM-UEG) of the State University of Goiás, Southeast Campus, Ipameri Unit - Ipameri-GO. Plant materials of the two species, S. bicolor and $D$. insularis, were collected manually in sorghum production fields and areas with natural infestations of weeds in agricultural environments, specifically in the plant production sector of Ipameri Campus. The seeds of the cultivated species used - Brassica napus (Canola) were of the Hyola 433 variety. A completely randomized design was used in a $2 \times 5$ factorial scheme (two extracts (D. insularis and S. bicolor) and five concentrations ( 0 , $25,50,75$, and $100 \%$ ), with four replicates of 50 seeds each.

First, seed tests were performed to establish the initial germination pattern of the lot, represented by $75 \%$. In order to do so, the canola seeds were placed in plastic boxes containing blotter paper moistened with distilled water with a volume of 2.5 times the weight of the paper and then conditioned in B.O.D chambers at $25^{\circ} \mathrm{C}$ and a photoperiod of $12 \mathrm{~h}$ of light where germination percentage was evaluated seven days after the seeding. Seeds that produce seedlings with all the essential parts visible (root and plumule) were considered germinated, regarded normal those that formed a shoot with cotyledons, as a developed hypocotyl and primary root (Brasil, 2009).

The extracts were prepared with the species $S$. bicolor and $D$. insularis, where samples of these materials were collected in the field, washed, crushed using a blender, and taken to the air circulation oven at $50{ }^{\circ} \mathrm{C}$ for 24 hours. The solutions were prepared by adding deionized water 
to 100 g.L $\mathrm{L}^{-1}$ of quantified material previously place inside a container. The blend was stirred to obtain a homogeneous mixture, left to decant for 24 hours. Subsequently, filtering was performed using filter paper, and then solutions of 25, 50, 75, and 100 g.L L $^{-1}$ were prepared by diluting the final extract (Zucareli et al., 2019).

The tests were carried out following the same procedure described above (germination test), except for the substrate moistening, where solutions of different concentrations $(25,50,75$, and $100 \%)$ were prepared from plant extracts, and a blank solution (0\%), corresponding to the control, was made using deionized water, keeping a water volume of 2.5 times the weight of the paper. There was no need to change the substrate for further wetting, either with distilled water (control) or with plant extracts in their different concentrations during the tests; therefore, variations in extracts concentration due to water addition on the same paper were avoided.

Variables evaluation, taken according to Brasil (2009), were reported as follows: percentage of germination $(\mathrm{G})$, where the seeds that produced normal seedlings with all essential parts visible, shoot with cotyledons as hypocotyl and primary root developed were considered germinated; the other seedlings were separated into abnormal ones (PA) and dead seeds (SM) for analysis of behavior inherent to the concentrations of the employed solutions. The length of 20 seedlings was determined as a test with the aid of a millimeter ruler, measuring the shoot (SL) and the primary root (RL) and, subsequently, added to compose the total size (TL) of the seedling. The ratio of these variables was calculated in percentage by the ratio of the shoot $(\mathrm{S} / \mathrm{T})$ and the root $(\mathrm{R} / \mathrm{T})$ given by the formulas:

$$
\begin{aligned}
& S / T=\frac{S L}{T L} \times 100 \\
& R / T=\frac{R L}{T L} \times 100
\end{aligned}
$$

where: SL - shoot length $(\mathrm{cm}) ; \mathrm{RL}$ - primary root length $(\mathrm{cm}) ; \mathrm{TL}$ - total length of seedlings $(\mathrm{cm})$.

The obtained data were initially subjected to normality tests (Kuiper and Watson), in which, when presenting normal distribution, variance analysis (ANOVA) was performed under a $2 \times 5$ factorial scheme (two extracts, from $D$. insularis and S. bicolor) and five concentrations $(0,25,50,75$ and $100 \%)$, with means compared by the Tukey test at $5 \%$ probability to differentiate the extracts and polynomial regression to study the behavior according to the concentrations of the plant extract. Sisvar 5.6 and SigmaPlot 10 software were used to assist the analysis.

\section{Results and Discussion}

Data analysis revealed a significant effect $(\mathrm{p} \leq 0.01)$ of two extracts studied for the different concentrations tested (Table 1). There was a significant interaction between treatments (Table 1), showing the influence of two extracts in different concentrations in canola cultivation.

Table 2 shows the differences between the average values between the studied species. It was observed that the $D$. insularis extract presented a greater interference, which was significant according to statistical analysis, where the variables of abnormal seedlings, shoot length and shoot ratio were more affected by this extract, compromising the seedlings' starting development. Thus, if applied on the field, these seedlings would suffer from the initial competition for light, so they would possibly be suppressed by weeds not being able to develop and reach adulthood.

For the evaluated germination parameters, dead seeds, primary root length, total length, and root ratio, it is noted that the $D$. insularis extract was highly harmful to the seed, interfering mainly on the root system formation, and difficulty in its settlement. This fact is shown in Figure 1, where it is observed a germination reduction of Brassica napus (Canola) at concentrations of 50,75 , and $100 \%$ of $S$. bicolor extracts, and even seeds death. In a study by Rizzardi et al. (2008) with Brassica oleracea cv. capitata and Brassica rapa, species of the same genus of canola, allelopathic effects were observed using aqueous extracts of Bidens pilosa leaves, both in germination and seedling growth, presenting similar results to those found in this work.

Table 1. Summary of the analysis of variance (ANOVA) for the physiological performance parameters of canola seeds, related to plant extracts and different concentrations, for germination (G), abnormal seedlings (AS), dead seeds (DS), shoot length (SL), primary root

\begin{tabular}{|c|c|c|c|c|c|c|c|c|c|}
\hline \multirow{2}{*}{ Source of variation } & \multicolumn{9}{|c|}{ P-value } \\
\hline & DF & $\mathrm{G}$ & AS & DS & SL & RL & $\mathrm{TL}$ & $\mathrm{S} / \mathrm{T}$ & $\mathrm{R} / \mathrm{T}$ \\
\hline Extracts (E) & 1 & $<0.01 *$ & $<0.01 *$ & $<0.01 *$ & $<0.05 * *$ & $<0.01 *$ & $<0.05 * *$ & $<0.01 *$ & $<0.01 *$ \\
\hline Concentration (C) & 4 & $<0.01 *$ & $<0.01 *$ & $<0.01 *$ & $<0.01 *$ & $<0.01 *$ & $<0.01 *$ & $<0.01 *$ & $<0.01 *$ \\
\hline \multirow[t]{2}{*}{ E x C } & 4 & $<0.01 *$ & $<0.01 *$ & $<0.01 *$ & $<0.01 *$ & $<0.05 * *$ & $<0.05 * *$ & $<0.01 *$ & $<0.05 *$ \\
\hline & & \multicolumn{8}{|c|}{ Mean Squares } \\
\hline Averages & - & 29.3 & 39.25 & 31.45 & 0.33 & 0.05 & 0.60 & 3.72 & 32.85 \\
\hline $\mathrm{CV}(\%)$ & - & 13.73 & 25.41 & 29.34 & 16.73 & 32.9 & 20.34 & 12.17 & 17.47 \\
\hline LSD & - & 5.83 & 6.47 & 5.98 & 0.03 & 0.27 & 0.07 & 47.14 & 3.72 \\
\hline
\end{tabular}
length (SL), total length (TL), shoot ratio (S/T) and root ratio (R/T). Ipameri-GO. LASEM / UEG, 2019

* Significant by the F-test $(\mathrm{P}<0.01)$; ** Significant by the F-test $(\mathrm{P}<0.05)$; ns not significant; DF: degrees of freedom. 
Table 2. Mean values of germination (G), abnormal seedlings (AS), dead seeds (DS), shoot length (SL), primary root length (SL), total length (TL), shoot ratio (S/T), and root ratio (R/T) according to the extracts and its concentrations. Ipameri-GO. LASEM / UEG, 2019.

\begin{tabular}{|c|c|c|c|c|c|c|c|c|}
\hline \multirow[t]{2}{*}{ EXTRACTS } & $\mathbf{G}$ & AS & DS & SL & $\mathbf{R L}$ & TL & $\mathbf{S} / \mathbf{T}$ & $\mathbf{R} / \mathbf{T}$ \\
\hline & \multicolumn{3}{|c|}{ 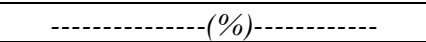 } & \multicolumn{3}{|c|}{-------------( $\mathrm{cm}$-------------- } & \multicolumn{2}{|c|}{--------(\%)-------- } \\
\hline D. insularis & $21 \mathrm{~B}$ & $66 \mathrm{~B}$ & $13 \mathrm{~A}$ & $3.5 \mathrm{~A}$ & $2.1 \mathrm{~B}$ & $5.6 \mathrm{~B}$ & $54 \mathrm{~A}$ & $26 \mathrm{~B}$ \\
\hline S. bicolor & $49 \mathrm{~A}$ & $12 \mathrm{~A}$ & $39 \mathrm{~B}$ & $3.1 \mathrm{~B}$ & $3.3 \mathrm{~A}$ & $6.5 \mathrm{~A}$ & $40 \mathrm{~B}$ & $60 \mathrm{~A}$ \\
\hline C.V. (\%) & 13.73 & 25.41 & 29.34 & 16.73 & 32.9 & 20.34 & 12.17 & 17.47 \\
\hline F-value & 147.6 & 19.53 & 18.21 & 6.882 & 3.250 & 2.893 & 10.78 & 10.78 \\
\hline
\end{tabular}

Means followed by a different letter in the column differ by the Tukey test, at $5 \%$ significance.

A.

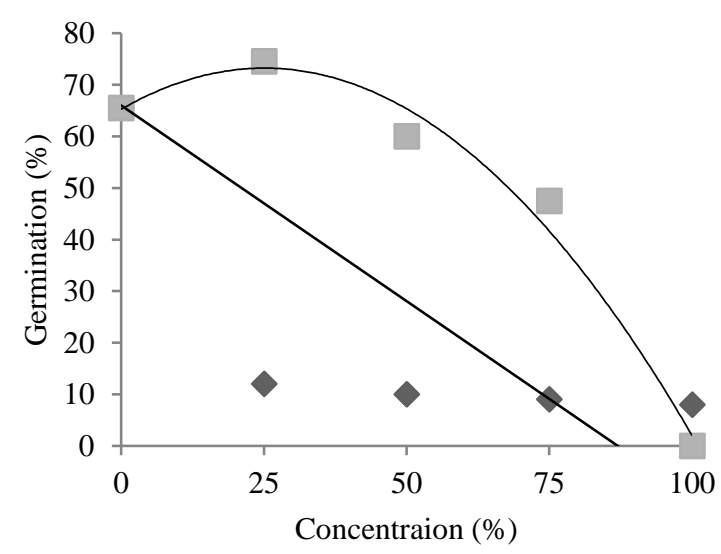

$\checkmark$ Digitaria insularis

Sorghum bicolor

C.

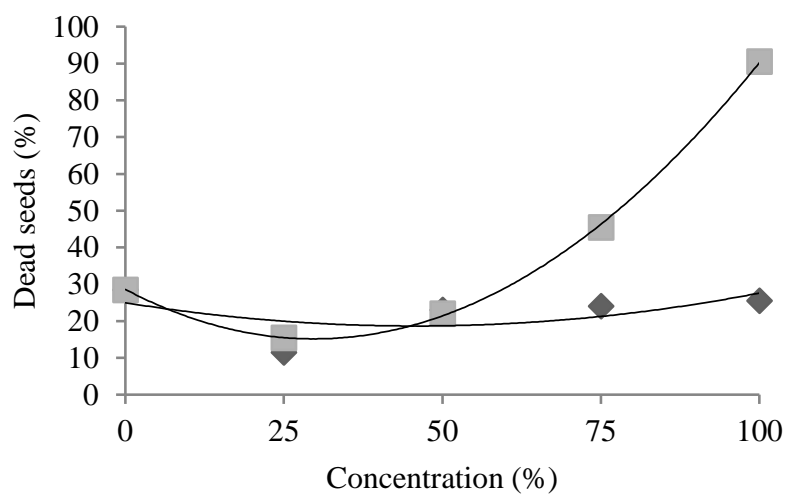

$\diamond$ Digitaria insularis

$y=0.003 x^{2}-0.2769 x+24.986 \quad R^{2}=0.62 *$

Sorghum bicolor $y=-0.472 x+44.5 \quad R^{2}=0.65^{*}$

$y=-0.0127 x^{2}+0.6366 x+65.243 \quad R^{2}=0.98$
B.

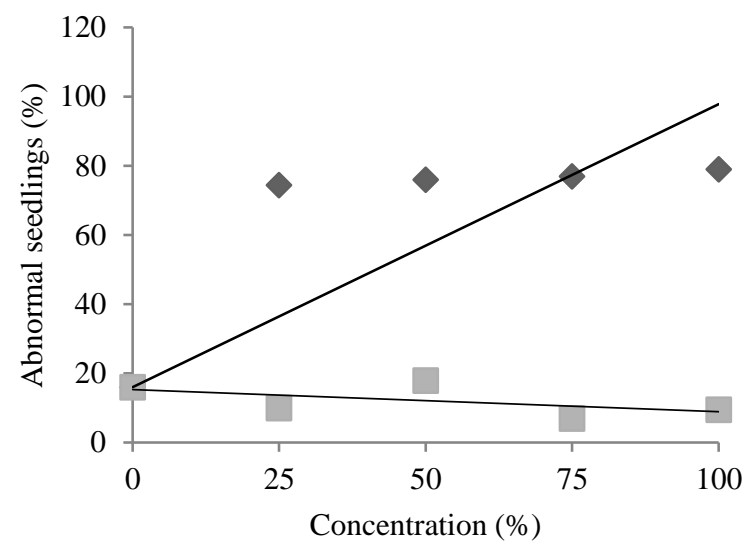

$\begin{array}{lrl}\text { Digitaria insularis } & \mathrm{y}=0.818 \mathrm{x}+16 & \mathrm{R}^{2}=0.56^{*} \\ \text { Sorghum bicolor } & \mathrm{y}=-0.064 \mathrm{x}+15.3 & \mathrm{R}^{2}=0.89^{*}\end{array}$

D.

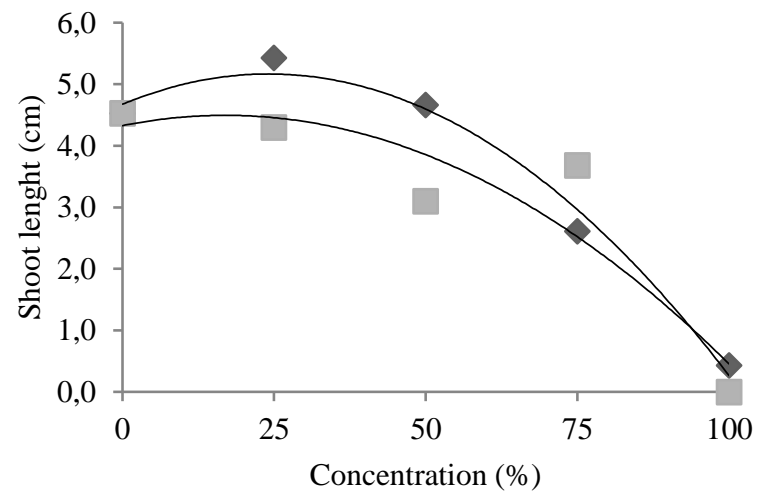

- Digitaria insularis

$y=-0.0009 x^{2}+0.0409 x+4.6731 R^{2}=0.98 *$

Sorghum bicolor

Figure 1. Germination (A), abnormal seedlings (B), dead seeds (C), and shoot length (D) of canola according to the aqueous extract obtained from plant materials of Digitaria insularis and Sorghum bicolor. * Significant at $5 \%$ probability by the t-test.

Germination results showed a quadratic increase of the means for aqueous extract of S. bicolor, where the point with the highest rate of normal seedlings $(73 \%)$ is found in the concentration of $32 \%$; for $D$. insularis extract, the linear adjustment of the data resulted in maximum germination of $66 \%$ (Figure 1A). The lowest estimates are found for the highest doses, with a concentration of $100 \%$ being critically harmful, regardless of the extract.
S. bicolor extract showed an influence on the germination rate of canola seeds, with a beneficial effect on the induction of germination in concentrations of $25 \%$. In the case of $D$. insularis extract, there was a drastic reduction in the rates of normal seedlings (Figure 1A).

The results obtained by Rizzardi et al. (2008) agree with the present study, suggesting that the allelopathic effects are influenced by the concentration of the 
metabolic substance present in the extract, negatively or positively interfering on germination. When evaluating the feasibility of using sorgoleone in the field, Uddin et al. (2013) were able to verify in their studies sorgoleone herbicidal activity against different weeds, as well as selectivity when applied in the form of wettable powder (WP); they also found germination inhibition of approximately $70 \%$ for gramineous species at a concentration of $0.2 \mathrm{~g} \mathrm{~L}^{-1}$.

Abnormal seedlings percentage analysis revealed that the concentrations of $D$. insularis extract promoted a linear rising in the averages, with the highest value of $79 \%$ abnormality for $100 \%$ concentration dose; that is, the increase in concentrations drastically affects seedling development (Figure 1B). Allelochemicals have different allelopathic effects on the plant's life cycle, varying according to the concentration and donor or recipient species (Alves et al., 2014). The extract of S. bicolor obtained an average of $12 \%$ of abnormality regardless of the dose, with no variation in the development of canola.

Allelochemicals are natural herbicides and insecticides, produced by plants as their self-defense mechanism; these compounds, when isolated, are potential sources for molds of new structural arrangements and sustainable agricultural management, less invasive to the environment (Silva et al., 2017). As observed in S. bicolor, the number of dead seeds grow with increased extract concentrations, exhibiting is a second-order dependence between these parameters (Figure 1C).

D. insularis extract has an average of $27 \%$ of dead seeds in the canola crop, regardless of the dose (Figure 1C). However, there is a high rate of abnormal seedlings, contributing to the failure development of the crops. Araújo et al. (2017) investigated the presence of allelopathic compounds extracted from the leaves of $C$. madagascariensis and their impact on the germination and initial growth of three native species of Brazil's semiarid region. It was reported that $C$. madagascariensis produces compounds with the potential to interfere in other plants under the evaluated conditions, due to its effects on Lactuca sativa. The authors indicated that the extracts contained allelopathic substances, which should be the cause of the negative effects on other species. However, this may be related to the greater sensitivity of the target plant.

When the shoot length was analyzed, a quadratic increase in averages was observed for the two extracts, with a smaller value of $4.49 \mathrm{~cm}$ for $S$. bicolor at a concentration of $17 \%$, and a higher value of $5.14 \mathrm{~cm}$ for D. insularis at $23 \%$ of the extract concentration (Figure 1D). It can be assumed that very low doses of these extracts can act as shoot stimulants; nevertheless, high doses inhibit the initial development of canola. Carvalho et al. (2014) stated that allelopathic compounds, in most cases, act as germination and growth inhibitors; however, some researches demonstrate their performance as growth agents when present in lower concentrations.

The reduction in the length of the primary root is associated with morphological changes when compared to the control seedlings (Figure $3 \mathrm{~A}, \mathrm{~B}$ ), with deformities in the epicotyl and the primary root of the seedlings exposed to the $D$. insularis extract, with twisted and disproportionate parts, and greater appearance of secondary roots. These characteristics are accentuated in higher extract concentrations (Figure 3), to the point that there are no longer normal seedlings in the germination test when $25 \%$ concentration is used, being statistically confirmed in Figure 2 A. According to Brasil (2009), seedlings with deformations are considered within the category of abnormal seedlings; that is, those that do not show potential to continue their development and give rise to normal plants.

For total length, the effect of the two extracts is analogous (Figure 2), in which a negative regression is observed, that is, the increase in concentrations reduced the potential for crops development in all cases, as seen in Figure 3, except for the control and Figure 3B, in which its development did not undergo major changes. Sorgoleone, a compound present in the extract of $S$. bicolor, possibly acts as a plastoquinone equivalent, interfering in plastoquinone binding to proteins in photosystem II (Santos et al., 2012), thus acting in the photochemical phase of photosynthesis and reducing the production of assimilates, resulting in less growth.

In the shoot ratio variable, is observed a quadratic increase for the averages of D. insularis and S. bicolor with the highest percentages of $88 \%$ and $60 \%$, respectively, with a dose of $43 \%$, that is, with low concentrations, the development of the epicotyl increased, as seen in Figure 3, for seedlings resulting from treatments with intermediate doses (Figure $3 \mathrm{C}$ and D). Carvalho et al. (2014) also observed the growthregulating effect in low concentration of the extracts when evaluating the effect of different extracts concentrations obtained from the straw of three gramineous: black oats (Avena strigosa Schieb), sorghum (Sorghum bicolor (L.) Moench) and millet (Pennisetum glaucum (L.) R. Brown) on the germination and development of lettuce seedlings.

In the root ratio variable, a quadratic reduction was observed for the averages of $D$. insularis and S. bicolor; that is, at the highest concentrations, there is less root development, as shown in Figure 3 for seedlings resulting from treatments with higher doses (Figure 2C). The disproportion between the roots and the shoot of the seedlings is due to the situation in which there is greater contact between the roots and the extract (phytotoxins) than with other structures of the seedlings (Chung et al., 2001). 
A.

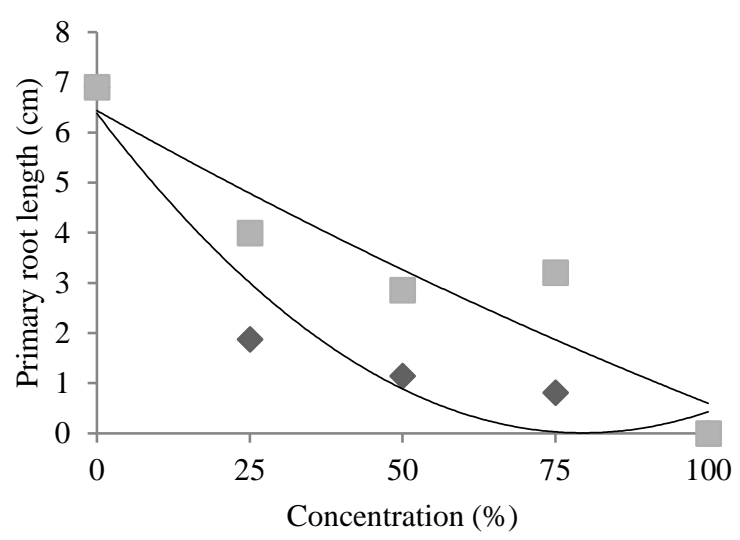

$\checkmark$ Digitaria insularis

Sorghum bicolor

$$
y=0.001 x^{2}-0.1602 x+6.3801 R^{2}=0.92 *
$$$$
y=0.0001 x^{2}-0.0685 x+6.4363 R^{2}=0.87 *
$$

C.

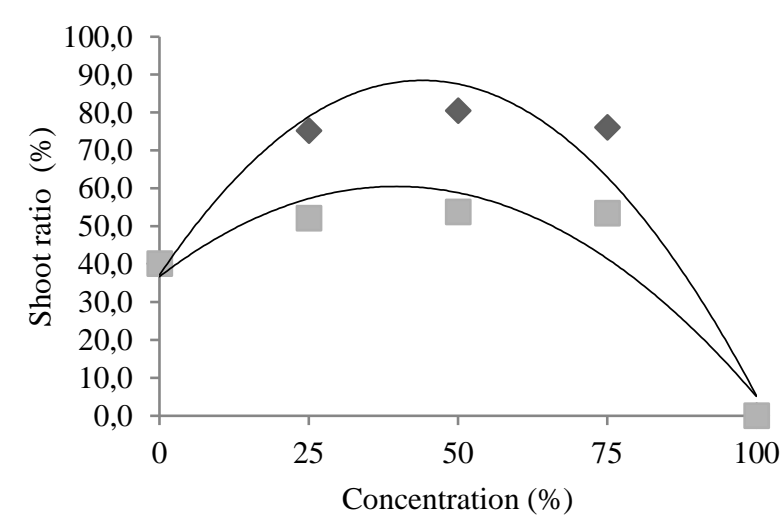

$\checkmark$ Digitaria insularis

$y=-0.0265 x^{2}+2.3333 x+37.141 R^{2}=0.94 *$

Sorghum bicolor
B.

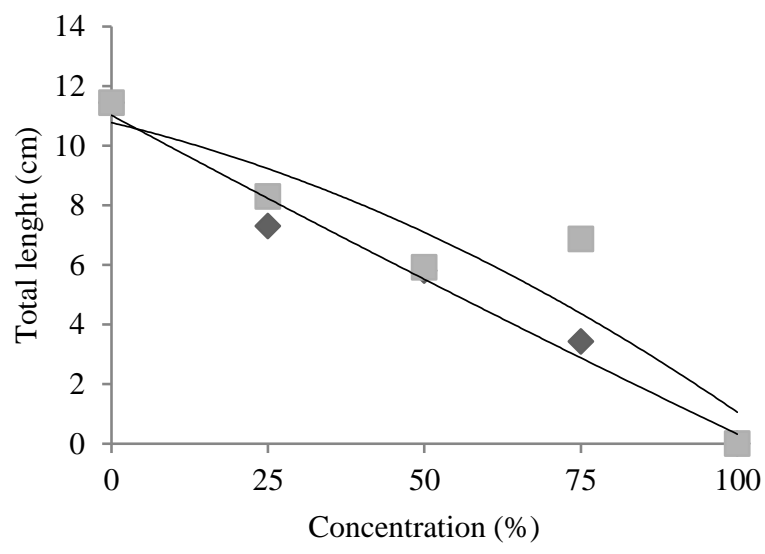

D.

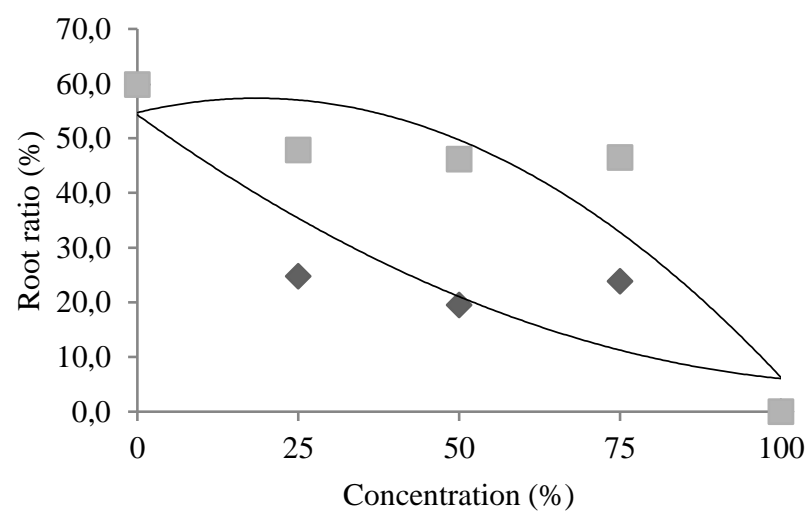

$\checkmark$ Digitaria insularis

$y=0.0037 x^{2}-0.8476 x+54.288 R^{2}=0.81 *$

Sorghum bicolor

Figure 2. Primary root length (A), total length (B), shoot ratio - S/T (C), and root ratio - R/T (D) of canola according to the aqueous extract obtained from plant materials of Digitaria insularis and Sorghum bicolor. * Significant at 5\% probability by the t-test.

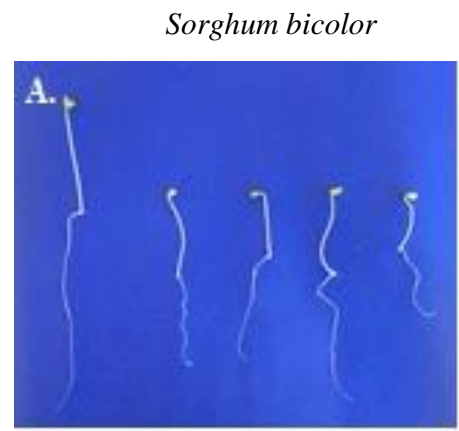

\section{Digitaria insularis}
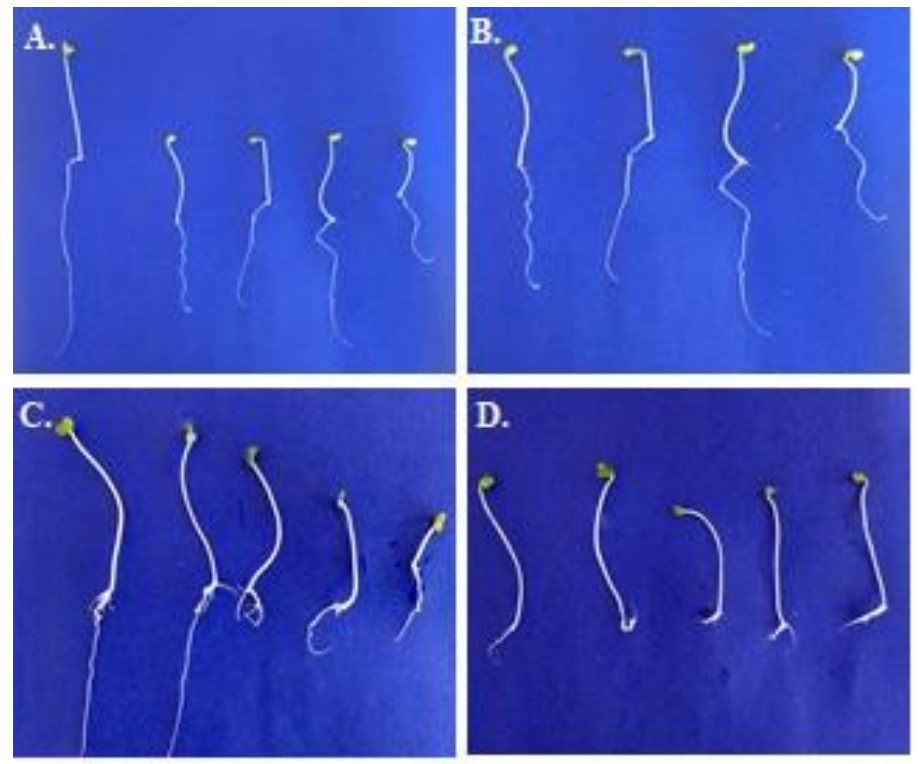

Revista de Agricultura Neotropical, Cassilândia-MS, v. 7, n. 4, p. 65-72, out./dez. 2020. 

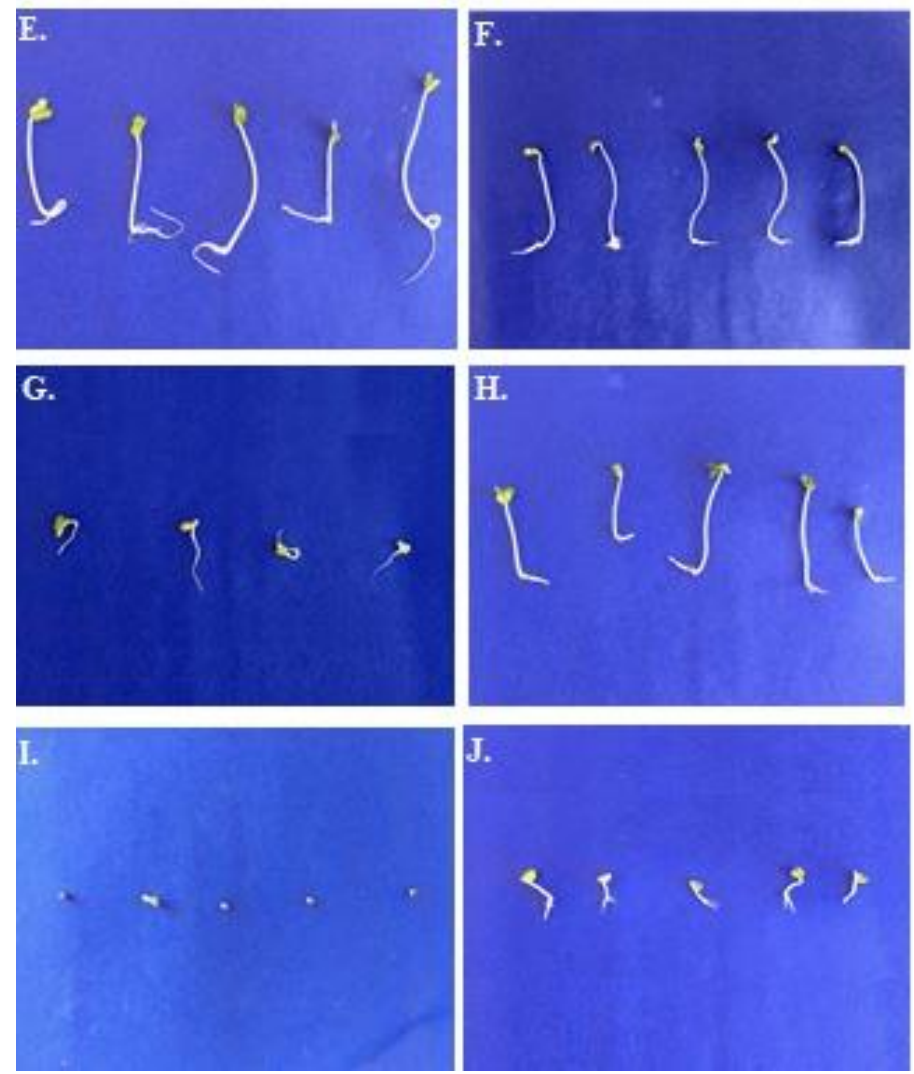

Figure 3. Canola seedlings from germinating tests using aqueous extracts of Sorghum bicolor and Digitaria insularis with concentrations of 0\% (A, B), 25\% (C, D), 50\% (E, F), 75\% (G, H), and 100\% (I, J). Ipameri-GO. LASEM/UEG, 2019.

Visual evaluation enables a more detailed perception of the harmful effects of the extracts, allowing even a visual diagnosis of the statistical results of the variables. This facilitates the identification of root malformation due to direct contact between root and substrate, becoming clearer when the development of the control parcels (Figure $3 \mathrm{~A}, \mathrm{~B}$ ) is compared with other submitted to different extracts and concentrations (Figure $3 \mathrm{C}, \mathrm{D}, \mathrm{E}$, F, G, H, I and J). These findings can be partially explained by the interactions of allelochemicals present in the extract of $D$. insularis and S. bicolor, with plant hormones in the meristematic cells of canola seedlings. In lettuce seed bioassays, when the shoot of the seedlings is evaluated, assimilation and, consequently, the concentration of allelopathic compounds in the root system are favored due to the physical contact of the root with the filter paper, exposed directly to the aqueous extract (Gonçalves et al., 2016).

Thereby, a relationship with auxin is suggested, as this regulator is associated with plant growth and playing a role in practically all aspects of development that includes the phenomenon of tropism when considered that its functions are regulated by the flow of auxin hormone in the root cap and apex of the coleoptile (Taiz et al., 2017). Therefore, plant extracts in different concentrations affected canola seeds germination, and the presence of allelopathic potential was verified in the seedling developmental characteristics.

\section{Conclusions}

D. insularis aqueous extracts interfere in all variables studied, which compromises the formation of normal seedlings, regardless of concentration. S. bicolor extract expressed allelopathic effects only in concentrations above $75 \%$. Both species can inhibit the initial development of canola plants.

\section{Bibliographic References}

Alves, M.C.S., Medeiros Filho, S., Manoel Neto, A., Brito, R.C., Araujo, R.C., 2014. Allelopathic effect of essential oils of medicinal plants in Bidens pilosa L. Revista Brasileira Plantas Medicinais, $\quad$ 16(3), 731-736. DOI: https://doi.org/10.1590/1983-084x/12_134.

Araújo, H.T.N., Brito, S.F., Pinheiro, C.L., Filho, S.M.A., 2017. Alelopatia aumenta o potencial invasor de Cryptostegia madagascariensis Bojer ex Decne.? Enciclopédia biosfera, 14(25), 1-12. DOI: 10.18677/EnciBio_2017A1.

BRASIL, 2009. Regras para Análise de Sementes. Ministério da Agricultura Pecuária e Abastecimento, 346 p.

Cargnelutti, A.F., Toebe, M., Alves, B.M., Burin, C., Kleinpaul, J.A., 2015. Estimação da área foliar de canola por dimensões foliares. Bragantia, 74(2), 139-148. DOI: http://dx.doi.org/10.1590/1678-4499.0388.

Carvalho, W.P., Carvalho, G.J., Neto, D.O.A., Teixeira, L.G.V., 2014. Alelopatia de extratos de adubos verdes sobre a 
germinação e crescimento inicial de alface. Bioscience Journal, 30(1), 1-11.

Chung, I.M., Ahn, J.K., Yoon, S.J., 2001. Assessment of allelopathic potential of barnyard grass (Echinochloa crus-gall) on rice (Oryza sativa L.) cultivars. Crop Protection, 20(1), 921928. DOI: https://doi.org/10.1016/S0261-2194(01)00046-1.

Dayan, F.E., Duke, S.O., 2014. Natural compounds as nextgeneration herbicides. Plant Physiology, 166(3), 1090-1105. DOI: https://doi.org/10.1104/pp.114.239061.

Dayan, F.E., Howell, J., Weidenhamer, J.D., 2009. Dynamic root exudation of sorgoleone and its in planta mechanism of action. Journal of Experimental Botany, 60(7), 2107-2117. DOI: $10.1093 / \mathrm{jxb} / \mathrm{erp} 082$.

EMBRAPA, 2018. Colheita de canola encerra com aumento na produção. https://www.embrapa.br/busca-de-noticias//noticia/39610765/colheita-de-canola-encerra-com-aumentona-producao (acessado 14 de junho de 2019).

Gonçalves, A.L.Z., Tonet, A.P., Stofell, A.V.S., 2015. Potencial alelopático das plantas daninhas sobre o desenvolvimento de plântulas de soja (Glycine max L.). Revista Eletrônica da Faculdade de Ciências Exatas e da Terra Produção/Construção e Tecnologia, 4(7), 52-59. DOI: https://doi.org/10.4025/actasciagron.v31i3.320.

Gonçalves, V.D., Coelho, M.F.B., Camili, E.C., 2016. Bioensaios em sementes de Lactuca sativa $\mathrm{L}$. com extrato de folhas de Kielmeyera coriacea Mart. \& Zucc. Revista Internacional de Ciências, 6(2), 160-170. DOI: https://doi.org/10.12957/ric.2016.21813.

Lessa, B.F.T., Andrade, M.N., Antunes, M.R., Reges, A.M., Medrado, E.S., Oliveira, I.S., 2019. Efeito alelopático de Pityrocarpa moniliformis na germinação do sorgo sacarino e plantas daninhas. Cultura Agronômica, 28(1), 50-64. DOI: https://doi.org/10.32929/2446-8355.2019v28n1p50-64.

Milciades, A.M.A., Duarte Júnior, J.B., Costa, A.C.T., Mezzalira, É.J., Piva, A.L., Santin, A., 2014. Características agronômicas e teor de óleo da canola em função da época de semeadura. Revista Brasileira de Engenharia Agrícola e Ambiental, $\quad 18(9), \quad 934-938 . \quad$ DOI: http://dx.doi.org/10.1590/1807-1929/agriambi.v18n09p934938.

Moreira, G.C., Mandrick, C., 2012. Alelopatia de extrato de capim-amargoso sobre a germinação de sementes de soja e milho. Cultivando o Saber, 5(1), 129-137.
Rizzardi, M.A., Neves, R., Lamb, T.D., Johann, L.B., 2008. Potencial alelopático da cultura da canola (Brassica napus L. var. oleifera) na supressão de picão-preto (Bidens sp.) e soja. Revista Brasileira de Agrociência, 14(2), 239-248. DOI: http://dx.doi.org/10.1590/S0100-83582008000400002.

Santos, I.L.V.L., Silva, C.R.C., Santos, S.L., Maia, M.M.D., 2012. Sorgoleone: benzoquinona lipídica de sorgo com efeitos alelopáticos na agricultura como herbicida. Arquivos do Instituto Biológico, 79(1), 135-144. DOI: http://dx.doi.org/10.1590/S1808-16572012000100020.

Seabra Júnior, E., Dal Pozzo, D.M., Santos, R.F., 2017. Estudo sobre a cultura de canola (Brassica napus $L$.) no contexto de culturas energéticas. Acta Iguazu, 6(5), 140-146.

Silva, C.P., Riccib, T.G., Arruda, A.L., Pagliosa, F.M., Macedoça, M.L.R., 2017. Extratos vegetais de espécies de plantas do Cerrado sul-matogrossense com potencial de bioherbicida e bioinseticida. Uniciências, 21(1), 25-34. DOI: https://doi.org/10.17921/1415-5141.2017v21n1p25-34.

Souza Filho, A.P.S., 2014. Alelopatia: princípios básicos e mecanismos de interferências, in: Monquero, P.A., (Ed.). Aspectos da biologia e manejo das plantas daninhas. Embrapa Amazônia Oriental, São Carlos, p. 83-101.

Taiz, L., Zeiger, E., Moller, I.M., Murphy, A., 2017. Plant Physiology and Development, sixth ed. Sinauer Associates, Sunderland.

Uddin, M.R., Park, S.U., Dayan, F.E, Pyon, J.Y., 2013. Herbicidal activity of formulated sorgoleone, a natural product of sorghum root exudate. Pest Management Science, 70(2), 252-257. DOI: https://doi.org/10.1002/ps.3550.

Uhlmann, L.A.C., Oliveira, R.J., Santos, M.G., 2018. Allelopathic effects of plant extracts of Hancornia speciosa Gomes on germination of Lactuca sativa L. Revista Fitos, 12(2), 147-160.

USDA, 2019. United States Department of Agriculture. https://apps.fas.usda.gov/newgainapi/api/report/downloadrepo rtbyfilename?filename $=$ Oilseeds $\% 20$ and $\% 20$ Products $\% 20 \mathrm{An}$ nual_Ottawa_Canada_3-15-2018.pdf (accessed May 15, 2019).

Zucareli, V., Coelho, E.M.P., Fernandes, W.V., Peres, E.M., Stracieri, J., 2019. Allelopathic potential of Sorghum bicolor at different phenological stages. Planta Daninha, 37(e019184017), 1-8. DOI: http://dx.doi.org/10.1590/s010083582019370100019 . 